\section{Cidade encruzilhada}

\section{Crossed city}

\section{Yuri Alexêevitch}

Universidade Federal da Integração Latino-Americana. Instituto de Cinema e Audiovisual.

\section{DESCRIÇÃO:}

Um olhar sobre a cidade-encruzilhada sul-americana. Este ensaio fotográfico foi realizado para a disciplina Introdução à Fotografia, ministrada em 2019.1, numa universidade federal brasileira. A tarefa proposta pelo professor foi a de fazer um ensaio fotográfico autoral. A partir do meu olhar estrangeiro, ainda desautomatizado, escolhi aproveitar essa condição efêmera, de estrangeiridade provisória, e passear pelo centro da cidade registrando instantes flagrados nessa espécie de flânerie ao coração latino-americano.

A cidade em questão fica na fronteira entre três países sul-americanos, formando assim uma grande encruzilhada de usos, costumes e práticas linguísticas. Nesse espaço de passagem cotidiana para os moradores dos três países, as diferenças são performatizadas, afirmam-se, mas também se complementam umas com as outras. Normalmente, o centro é o lugar mais agitado da cidade, onde os habitantes e os turistas costumam dividir espaços e passar o tempo. Nele, em meio ao turbilhão de informações, foi feito este ensaio.

Com um olhar habituado ao excesso de frio e a paisagens cinzentas típicos ao mês de março na região nórdica - de onde venho -, a explosão de luz e de cores características do espaço sul-americano foram os primeiros elementos a prenderem o meu olhar.
Nesse sentido, pode-se identificar de imediato a luz natural e as cores quentes como as marcas mais fortes dessas passagens ao sul.

Em meio ao turbilhão formado pela aglomeração circunstancial de transeuntes, automóveis, vendedores de rua anunciando seus produtos em pregões cadenciados, turistas, o excesso de calor e de umidade, tentei registrar momentos fugazes, aparentemente sem grandes importâncias no cotidiano moroso e urgente dos habitantes da cidade tríplice.

O proteger-se do sol implacável do sul; o proteger-se do perigo presente nos obstáculos citadinos; o proteger-se das circunstâncias socioeconômicas impostas; o proteger-se da ameaça iminente da violência urbana; o proteger-se enfim, e, em meio à sobrevivência, alguns flashes de poesia.

Curiosamente, muitos objetos fotografados nos falam sobre o lugar e as pessoas que os possuem e que, visualmente, podem pertencer aos três espaços que, ali, tornam-se um espaço/tempo único. Nas varandas abertas ao sol, numa das ruas mais movimentadas da cidade, era possível distinguir objetos domésticos dos seus habitantes, uma secadora de roupa, uma rede, algumas cadeiras, algum tipo de entulho acumulado ao sol. Tudo aqui é luz. Tudo aqui é cor. Tudo aqui é vida. Sob sol e umidade onipresentes, tudo parece germinar. Tudo é promessa e dever. 



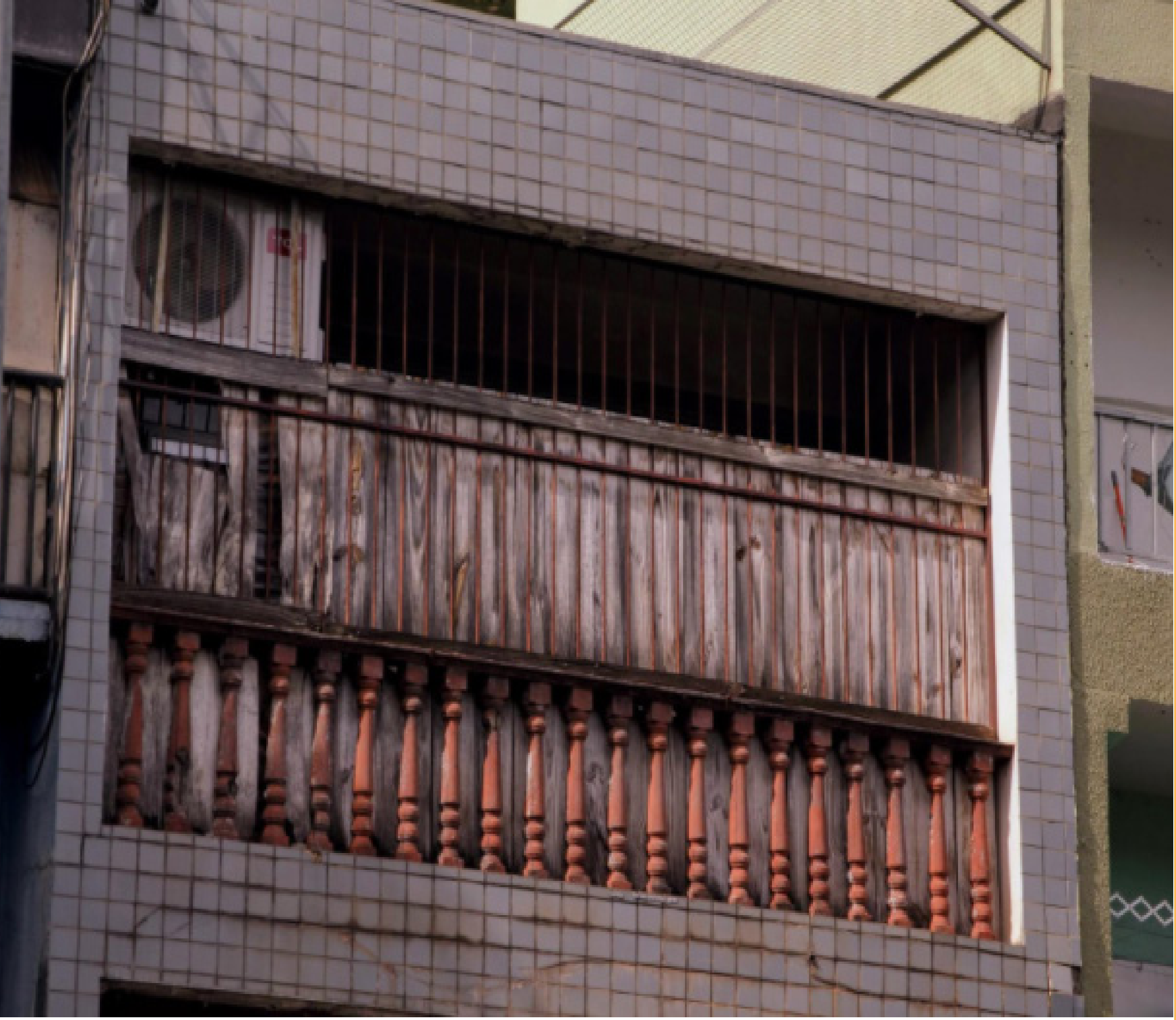

"SUCURITIZAÇÃO"

\section{SUCU}

R I T I

Z A

Ç Ã 0 
